\section{$\angle B B R$ \\ ILIAN BUSINESS REVIEW \\ v. 13, n.5 \\ Vitória-ES, Sep.-Oct. 2016 \\ p. 1 - 26 ISSN 1808-2386}

\title{
Interactivity and Explicit Memory Formation of Consumer Undergraduate Male Students on Internet Environment
}

\author{
George Bedinelli Rossi ${ }^{\dagger}$ \\ Escola Superior de Propaganda e Marketing - ESPM \\ Dirceu da Silva ${ }^{\Omega}$ \\ Nove de Julho University - UNINOVE \\ Mauro Neves Garcia ${ }^{¥}$ \\ (In Memoriam)
}

\begin{abstract}
This research aims to integrate the theories of Explicit Memory and Interactivity, contributing to the theoretical development of both. We investigated whether the interactivity precedes the explicit consumer memory. Data collection was carried on by sending online questionnaire to 876 undergraduate male students, with a return of 453 valid questionnaires. Data were analyzed using Structural Equation Modeling of the constructs Explicit Memory and Interactivity. The analyzes indicate that interactivity increases explicit consumer memory, filling a theoretical gap of this concept about its effects. Moreover, it is a concept related to the future, not only to the past and to present, as shown by the classical definitions. As for explicit memory, its formation results from the individual's interactions with the environment, which was not explained by classical theories. The results indicated that interactivity and explicit memory are almost independent of each other, having low correlation or almost nil.
\end{abstract}

Keywords: Interactivity. Explicit memory. Internet. Undergraduate students.

Received on 10/27/2014; Reviewed on 04/09/2015;Accepted on 07/06/2015; Divulgued on 09/05/2016.

\begin{tabular}{|c|c|c|}
\hline$\dagger$. Doctor & $\Omega$ Doctor & $¥$ Doctor (In Memoriam) \\
\hline Link: School Top of Advertising & Link: Nove de Julho & Link: \\
\hline and Marketing - ESPM / Master's & University - UNINOVE & Address: \\
\hline and Doctoral Program in & Address: Via das & E-mail: \\
\hline International Business - PMDNI & magnólias, 1000 - casa 14. & \\
\hline Address: Rua Catanduva, 119, & Jardim Colibri, Cotia/SP - & \\
\hline Pacaembu, São Paulo/SP - Brazil. & Brazil. Cep 06713-270. & \\
\hline Cep. 01246-060. & E-mail: & \\
\hline $\begin{array}{l}\text { E-mail: george.rossi@gmail.com; } \\
\text { gbrossi@usp.br; george@espm.br }\end{array}$ & dirceuds@gmail.com & \\
\hline
\end{tabular}

Note from the Editor: This paper was accepted by Bruno Felix. 


\section{INTRODUCTION}

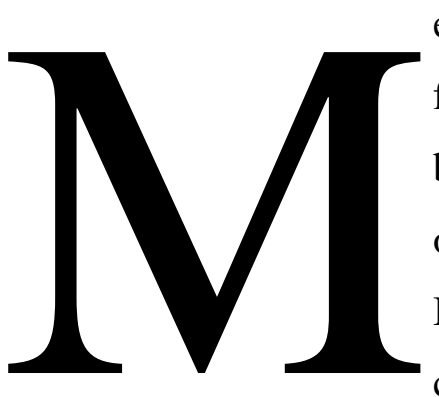

emory is usually discussed and characterized as a system that facilitates the storage of information - acquired through the interactions between the environment and an agent - and the subsequent recovery of that information relating to a behavior (WOOD; BAXTER; BELPAEME, 2013). The two predominant approaches about memory comprises of the storage of information that do not change, are static and may deteriorate over time (ROEDIGER, 1990) and learning (transfer appropriation process) (TOTH; HUNT, 1999).

The approach with regard to learning has incremented the findings by Bartlett (1935) and Neisser (1976), according to whom people are living organisms that seek and obtain necessary information for their adaptation and development, by moving around and interacting with the environment in which they find themselves. In this research, organisms change as they interact with their environment; this way, memory is seen as an interaction of past experiences with the present situation (RUBIN et al.2011).

For Paller, Voss, Westerberg (2009), this quest for information to adapt and evolve is a conscious process that involves complex mental functions that guide our daily activities such as perception, imagination, problem solving, attention, action and our sense of "self". Explicit memory is of particular interest because it focuses on the potential of consciousness of the individual and their effort to recover information (PALLER et al.,2009), considered by Wood et al. (2013) as a unique characteristic of human beings.

There are complex functions that impose the structure of the space-time relation of the information of an event, so as to organize the behavior of complex social relations dependent on the ability to remember. And, to use in a structured way the information of past interactions on who, what, when and where, corroborating the ideas of Cohen, Poldrack and Eichenbaum (1997) and Schacter (1996) and Tulving (2002).

Paller et al. (2009) assert that the explicit memory (composed by fragments of information connected by the encoding process) brings representations which are related in the space-time context, forming associations of ideas, concepts and past events. And this shapes the memory of a previous episode through multiple sensory modalities such as color, sound and connections with events that preceded and are related to those to follow. This relationship of past and current events is the essential feature that generates Interactivity (STEUER, 1992; RAFAELI; SUDWEEKS, 1997; JOHNSON et al., 2006). 
Domagk, Schwartz and Plass (2010), when defining Interactivity as a means of information exchange, claim that it increases as more sensory channels (such as hearing and vision) show evidence similar to those proposed by Paller et al. (2009) for explicit memory formation, supporting the findings by Stromer-Galley (2000), for whom interactivity is a variation of use of sensory channels or mental paths.

For Voorveld, Neijens and Smit (2011) despite Interactivity not being an exclusive feature of the Internet, it is the communication means of greater Interactivity among all others, supporting the findings by Mudambi and Schuff (2010), for whom greater interactivity increases the relation of thought with the individual's interest, which expands knowledge about navigating the site. This knowledge expansion on how to navigate the site, resulting from Interactivity, facilitates the customization of sites, creating expectations of what will happen (VAN NOORT; WILLEMSEN, 2012) and that increments the individual's explicit memory (VAN NOORT; VOORVELD; VAN REIJMERSDAL, 2012).

The Internet is an interactive communication medium that facilitates the search for information (VAN NOORT; WILLEMSEN, 2012); this research investigates whether interactivity antecedes the formation of explicit memory and identifies which Internet interactivity factors facilitate the search and recovery of information that form explicit memory (PALLER et al., 2009), verifying the relationship between interactivity (INTERA) and explicit consumer memory (MEMO). The study unit was formed by male undergraduate students, in the final stage of the course.

\section{LITERATURE REVIEW}

For the structuring of this research, we reviewed national and international publications on Interactivity, Explicit Memory, in order to define the bases of the research, the constructs and the variables that were measured, which follows:

\subsection{INTERATIVITY}

Van Noort and Willemsen (2012) claim that the concept of interactivity has a long history, but its importance is reborn since it deals with the internet's main competitive advantage compared to other media. For these authors, the interaction takes place between the user and the message, which is initiated by the action of clicking on an advertisement, which is the main difference from other media.

The exposure to view the message content, which is a voluntary act, leads to a more active and intense information processing in relation to the passive exposure of the user. For 
Rafaeli and Sudweeks (1997), interactivity occurs when a message refers to a previous one, that is, the messages relate to each other in a sequential and temporal manner.

Hence, Regan (1997) evolves the above authors' ideas by applying them to the Internet environment by stating that the human-computer interaction involves four stages: (1) there is a visual track - advertisement, (2) there is hand movement towards the specific target - the advertisement, (3) there is a click on the target, cursor positioned on top of the advertisement (4) and there is a response to the request made: the desired response is obtained.

Domagk et al. (2010) and Jiang et al. (2010) emphasize that this voluntary exposure to the internet environment generates greater attention to the message and activates the learning process more intensely. After the initial action of clicking a notification, users have the option to perform more actions in search of data of their interest, thus creating more opportunities to generate processing information through the interaction with the message, such as the search for content, looking into further sites and flag them for future reference.

According to Lombard and Snyder-Duch (2001), the application of interactive modes and of natural, intuitive and objective gestures increases the efficiency of the human-computer relationship regarding the execution of tasks. The naturalness and the intuition of gestural interaction forms results from individual's characteristics and motor-sensory abilities, signal integration, hand mimics and gestures that were culturally conditioned in people on their daily tasks, such as the act of pointing one's finger to indicate an object.

For the above authors, the quality of the gesture, in particular on manual interaction is oriented for maximum usefulness of adaptation and dexterity of the human hand. Trivial gestural interactions, such as shaking hands and waving one goodbye, are easy to be learned and applied, for they are independent of linguistic knowledge. The greatest advantage lies in the integrity, or honesty, of the gestural interaction; the hand serves as an immediate environment.

Sweller (2010) asserts that the human-computer interaction makes the user of this media to retain information or episodes in their memory for uses in future situations. For McMahan, Hovland and McMillan (2010) this withholding of information occurs because the user perceives the information received as a bonus for using this media in order to meet a perceived necessity as a problem that requires solutions.

According to Bellman and Rossiter (2004), potential solutions perceived by the public and provided by the structure of the Internet allow a greater range of information search that 
are associated with each other, contributing to the resolution of the problem in a shorter time, in comparison to other media such as books and television. This approach complements Coyle and Thorson's (2001), for whom the human-computer interaction will be the more efficient the lower the response time to the request made is.

Simmons (2009) adds that when the Human-Computer Interaction is increased by dimensions such as response time and useful information, it leads to the expansion of knowledge concerning the object - in this case, the website - through interconnections of multiple exposures, associating messages. Thus, Simmons (2009) accepts contributions from both Steuer (1992) who asserts that (i) response time along with (ii) mapping (ability to change the environment) and (iii) reach (range of used communication channels) are important factors to create Interactivity as well as from Rafaeli and Sudweeks (1997), for whom Interactivity is the extent to which various messages are related and linked together, as the last messages are related or associated with the previous ones. Thus, interactivity is the extent by which the communication is reflected back on itself and responds to the past (RAFAELI; SUDWEEKS, 1997) in minimum time (STEUER, 1992).

According to Steuer (1992) and Lombard and Snyder-Duch (2001), interactivity is the extent by which users can participate in modifying the form and content of a mediated environment in real time; for example, when the sponsor of an address encourages its users to comment on the presentation through electronic mail, or when the user clicks on an image and it increases or decreases in size.

Corroborating the authors above, Griffith and Chen (2004) show that the most interactive virtual stores are those that allow their users to experience or change clothes on virtual models, in other words, these actions, by altering the environment because users can change clothes in the virtual store environment, are more interactive. Para Mudambi and Schuff (2010), the higher the interactions with a website, more users know where to click due to the higher relation between thought and subjects of interest

Stromer-Galley (2000) considers interactivity as a variation of combinations of content and communication, and once it generates different ways of presenting the information, creates a meeting point with the consumer through the greater number of mental paths or associations. For Domagk et al. (2010), interactivity is a way to exchange information through the person-to-person or person-technology relationship with the purpose of influencing the behavior or knowledge of at least one person. 
In this information exchange, interaction increases as more channels are used for verbal and non-verbal communication, because a greater number of these channels facilitates message context, increasing information exchange related to each other. Thus, the greater variety in forms of communication facilitates information exchange and understanding it through associations between the different modes of message presentation (SUN; HSU, 2012), because more tracks, redundant or complementary information with each other are produced. For Steuer (1992), three factors contribute to interactivity:

a) Interaction speed: it is the response time. It is the rate at which a data can be assimilated by the mediated environment, which allows low-resolution computer games seem as real as car racing, since the response is extremely fast. In these games, to a given command, there is an immediate response;

b) Radius or reach of interactivity: number of attributes of the mediated environment that can be manipulated, controlled by the user and the total of possible variation within each attribute. This variable depends on the characteristics of the media in question. Dimensions that can be modified, or handled, are:

b.1) temporal order: number of possible actions at a given time. Television allows a small number of actions in a specific moment, and the video tape allows one to pause, forward and rewind the film, to repeat images or scenes from the film and to freeze these images according to the user's choice;

b.2) spatial organization: the way in which objects appear. Operations such as "copy and paste" are examples. This type of operation allows one to organize information in the most convenient way for the user;

b.3) intensity of sounds and image such as brightness and contrast: television, radio and computers allow greater variation in intensity as opposed to media that are not electronic or digital, such as printed media;

b.4) timbre or color frequencies: are variations of information in time dimension, different to intensity such as treble or bass sounds that are variations in signal amplitude. In the case of colors, variations in the frequency change color and its shades. 
c) Mapping. It is the way by which human actions are connected to actions within the mediated environment. These can be arbitrary and unrelated to the function performed, or they can be natural in the sense that human actions are coherent with the functions performed in the mediated environment. The first happens when somebody types in commands on the computer keyboard at random, as the visualization of the prospect of an object. The second occurs when there is the handling of the car's wheel or commands that represent the car's wheel by following the specific course in a race car in a computer game.

Corroborating authors mentioned above, Kim, Spielmann and McMillan(2012) emphasize the concept of active control as interactivity, as Ariely (2000) demonstrated in online purchasing controlled environments: greater control levels increase memorization of previous episodes.

For Griffith and Chen (2004), the alteration of environment by users reveals an intention to complete an activity at a specific time in the future, which according to Meilán et al. (2011), is an expectation. For Marsh, Cook and Hicks(2006), the main characteristic of an expectation is the joint occurrence in time of this expectation with other tasks that the user performs. According to Ko, Cho and Roberts(2005), the greater interactivity through the changing of the environment occurs by clicking parts of the Website.

Complementing these authors, Van Noort and Willemsen (2012) claim that when users customize sites in which they navigate, they create expectations of what will happen when they click on parts of the site that personalize Websites of their interests.

\subsection{MEMORY}

For Schacter (1996) and Mulligan (2012), memory is a dynamic process segmented into three bases: temporal, as short and long term memory; content, considering the episodic aspects; semantic and procedural and conscience, considering implicit and explicit memory. For Szpunar (2010), memory for a particular event is dynamic in itself and subject to change, which contrasts with the old static visions of memory. The static approach considers that an advertisement creates a specific memory trace which decreases with time; failure in remembering an advertisement is due to the inability of finding the right track to access ones content (VERDE, 2004).

Another view asserts that advertising memory interacts with other information stored, for example, when someone remembers an advertisement, either by personal experiences with 
the brand exposed in advertising, or by word of mouth information about the brand (LAVIE, 2010). Thus, when a consumer sees an advertisement, concepts are activated which are connected to its implementation, brand, message and correspondent, and the more repetition occurs from a particular connection, the stronger and more automatic the associations between concepts will be (BRAUN-LATOUR; LATOUR, 2004), leading them to connect through a network: when one is activated, others will be activated.

For Weldone Massaro (1996), the integration of multiple sources of information provides the user with multiple tracks that, once combined, facilitate past recollection of events or episodes. For Kan et al.(2011), multiple memory tracks produce better results than single tracks, greater variety of tracks or information about a subject entails more effective memory of an episode.

\subsection{EXPLICIT MEMORY}

Explicit or declarative memory, originates from someone's exposure to any event when a representation of the information is encoded in memory, which is then associated with a space-time context linking the above event information (LEE, 2002). Thus, explicit memory is characterized when a consumer deliberately thinks of an event that has already occurred and intentionally tries to access the information that was presented at this past event. Measures related to this memory involve tests that directly refer to the past event; at this point, respondents are requested to demonstrate their knowledge on the past event (MULLiGAN, 2012).

Explicit memory is divided into episodic and semantic (WOOD et al., 2011). Episodic supports the retention and retrieval of personal experiences and refers to the ability to remember what happened, i.e., when and where the events or episodes took place (TULVING, 2002); this is a sequence of past events related to each other that are remembered. Semantics refers to symbolic information about events without context or concepts; according to the physical symbol system hypothesis, the use of symbolic representations prevails in semantic information (WOOD et al., 2011).

Episodic memory occurs when whilst performing a task, one consciously uses the information that has been recently exposed, trying to retrieve the information from previous exposure; in this process, when the information retrieved occurs by means of symbols, as words, generating concepts as a result of perceptual categorization, then semantic is obtained (WOOD et al., 2011). 
Kemp et al. (1984) indicated that the lowest variety and quantity of verbal and nonverbal tracks promote remembrance of actions with specific purposes, and that more verbal tracks, words, promote specific or arbitrary actions. Furthering the assertions of Kemp et al. (1984), Van Noort et al. (2012) state that communication with less variety of formats, in particular, those based on text, as they increase memorization, tend to favor the customization of a Website.

\subsection{DEMOGRAPHIC DIFFERENCES ON INTERNET USE AND MEMORIZATION}

As for the behavior on the Internet, McMahan et al. (2010) and Liu and Shrum (2009) assert that men are more oriented to performing tasks, use more complex tools, emphasize mostly convenience and purchase results with less time, indicating that they aim mainly at utility. Women are more oriented to communication and social relationships; emphasize the search for emotional, affective and social situations and the ease of use; that is, they aim at hedonism.

Baron-Cohen, Knickmeyer and Belmont(2005) explain gender differences on the Internet through the empathizing-systemizing theory. According to this theory, women in general are empathetic for responding to stimuli with the appropriate emotion, and men are systematizers for responding to stimuli by analyzing the relationship of stimuli with results and for deducing rules that govern systems.

Mak et al. (2009), by applying this theory, conclude that women often activate parts of the brain related to emotions and affectivity (limbic structures) while men activate the associated parts to cognition (prefrontal cortex, dorsolateral and ventromedial).

As for memory, men and women differ. For Cosgrove, Mazure and Staley (2007), the hippocampus, the part of the brain related to memory, is larger in women than in men and it is activated mostly in women when in situations of risk or low confidence, Internet characteristics. This absence of real active tracks plus the hippocampus in women than in men favoring a higher retention of events.

For McMahan et al. (2010), undergraduate students do not require more time on the Internet and have higher expectations for interactivity, which is corroborated by Correa et al. (2010), whose findings show that students seek more novelties, are more curious are more curious and have more connections with other people, both on the Internet and in the real world. Kan et al. (2011) show that older people need more time to identify perceptual representations and that young people have more visual processing speed, highlighting that 
the explicit memory is highly susceptible to aging. The same fact occurs in the verbal domain, memorization of verbal and visual associations are more effective for young than for older people.

\subsection{CONSOLIDATION OF CONSTRUCTS}

After the literature review, we formulated the main constructs (INTERA and MEMO) and the variables that were used in Likert scale format. Table 1 presents the literature synthesis used to formulate the assertions of a scale built and the authors that suggest them (SUN; HSU, 2012).

\begin{tabular}{|c|c|c|c|}
\hline Construct & Scale Variables & Operationalization of variables & References \\
\hline \multirow{8}{*}{$\begin{array}{l}\text { INTERA: } \\
\text { interactivity }\end{array}$} & \multicolumn{3}{|c|}{ IV - Speed: } \\
\hline & $\begin{array}{l}\text { IV1 - possibility of actions that } \\
\text { alter the environment. }\end{array}$ & $\begin{array}{l}\text { Sites that allow you to put folders, } \\
\text { icons, and files where you want are } \\
\text { easier to be navigated. }\end{array}$ & $\begin{array}{l}\text { Steuer (1992); } \\
\text { Lombard and Snyder- } \\
\text { Duch (2001); Johnson } \\
\text { et al. (2006) }\end{array}$ \\
\hline & $\begin{array}{l}\text { IV2 - response time of the site } \\
\text { to a request that was made. }\end{array}$ & $\begin{array}{l}\text { When quickly get the information they } \\
\text { want in a website, it reminds me in } \\
\text { some way, other information on the } \\
\text { previous page. }\end{array}$ & $\begin{array}{l}\text { Bellman e Rossiter } \\
\text { (2004);Coyle and } \\
\text { Thorson (2001); } \\
\text { Johnson et al. (2006) }\end{array}$ \\
\hline & \multicolumn{3}{|c|}{ IA - Reach: } \\
\hline & $\begin{array}{l}\text { IA1 - total actions that the } \\
\text { environment allows }\end{array}$ & $\begin{array}{l}\text { Sites that lets you choose the features } \\
\text { you want to use makes you remember } \\
\text { how you chose the functions. }\end{array}$ & $\begin{array}{l}\text { Steuer (1992); Johnson } \\
\text { et al. (2006) }\end{array}$ \\
\hline & $\begin{array}{l}\text { IA2 -the possibility of the user } \\
\text { organizing information as they } \\
\text { want }\end{array}$ & $\begin{array}{l}\text { I prefer sites where I can organize } \\
\text { information as I want. }\end{array}$ & $\begin{array}{l}\text { Rafaeli and Sudweeks } \\
\text { (1997); Johnson et al. } \\
\text { (2006) }\end{array}$ \\
\hline & \multicolumn{3}{|c|}{ IM - Mapping: } \\
\hline & $\begin{array}{l}\text { IM1 - natural actions for the } \\
\text { individual }\end{array}$ & $\begin{array}{l}\text { The more natural the movements were } \\
\text { made to navigate a site, more easily } \\
\text { you remember how to perform the } \\
\text { task. }\end{array}$ & $\begin{array}{l}\text { Lomabard and Snyder- } \\
\text { Duch (2001); Johnson } \\
\text { et al. (2006) }\end{array}$ \\
\hline \multirow{2}{*}{$\begin{array}{l}\text { MEMO: } \\
\text { Consumer } \\
\text { Explicit } \\
\text { memory }\end{array}$} & \multicolumn{3}{|c|}{ MR - Visual Acknowledgement: } \\
\hline & $\begin{array}{l}\text { MR1 - the user knows where } \\
\text { to click to get the desired } \\
\text { information. }\end{array}$ & $\begin{array}{l}\text { Whether you can organize the site as } \\
\text { you want, it makes you more easily } \\
\text { remember where you click. }\end{array}$ & $\begin{array}{l}\text { Lombard and Snyder- } \\
\text { Duch (2001) }\end{array}$ \\
\hline
\end{tabular}




\begin{tabular}{|c|c|c|}
\hline $\begin{array}{l}\text { MR2 - the user has expectation } \\
\text { of what will happen before } \\
\text { they click, that is, they do not } \\
\text { expect surprises like unwanted } \\
\text { 'banners'. }\end{array}$ & $\begin{array}{l}\text { Whether you can organize the } \\
\text { information makes you feel more } \\
\text { secure in using this site. }\end{array}$ & $\begin{array}{l}\text { Lee, 2002; Shapiro and } \\
\text { Krishnan, } 2001\end{array}$ \\
\hline \multicolumn{3}{|c|}{ MA -Number of associations, or knots, between concepts and/or ideas: } \\
\hline $\begin{array}{l}\text { MA1 - for a given information, } \\
\text { the user associates it with } \\
\text { others. }\end{array}$ & $\begin{array}{l}\text { When on a website, clicking on a } \\
\text { specific part quickly get the } \\
\text { information they wanted, this makes } \\
\text { me think of other things. }\end{array}$ & $\begin{array}{l}\text { Singh, } \\
\text { Balasubramanian and } \\
\text { Chakraborty (2000) }\end{array}$ \\
\hline $\begin{array}{l}\text { MA2 - associations have high } \\
\text { correlation with previous } \\
\text { activities. }\end{array}$ & $\begin{array}{l}\text { The greater the variety of information } \\
\text { that the user receives from a subject } \\
\text { one is researching, the more one } \\
\text { remembers the actions previously } \\
\text { done. }\end{array}$ & $\begin{array}{l}\text { Lee, 2002; Shapiro and } \\
\text { Krishnan, } 2001\end{array}$ \\
\hline \multicolumn{3}{|c|}{ MN - Sensory-motor recognition: } \\
\hline $\begin{array}{l}\text { MN1 - for a given task, the } \\
\text { user remembers several } \\
\text { episodes of how to accomplish } \\
\text { it. }\end{array}$ & $\begin{array}{l}\text { The more information I get on the } \\
\text { subject researched, or interest at the } \\
\text { time, but I remember previous } \\
\text { information on the subject researching. }\end{array}$ & $\begin{array}{l}\text { Ko, Cho and Roberts } \\
(2005)\end{array}$ \\
\hline $\begin{array}{l}\text { MN2 - words are more easily } \\
\text { remembered than images. }\end{array}$ & $\begin{array}{l}\text { Websites on which I can see images, } \\
\text { films, texts or sounds make me } \\
\text { remember other things. }\end{array}$ & $\begin{array}{l}\text { Kemp et al. (1984) and } \\
\text { Poster (1990) }\end{array}$ \\
\hline
\end{tabular}

Table 1 - Constructs and variables to be measured and authors that indicate them

\section{RESEARCH PROBLEM AND OBJECTIVE}

Lee (2002) states that explicit memory is composed of fragments of information that, when gathered by the coding process, increment the relational representations, and that according to Paller et al. (2013) highlights the memory of an event or episode, with sufficient details for the reminder of the source of information. These details for the recollection of an episode may include the arrangement and the spatial and temporal location of stimuli as objects and people, information from multiple sensory modalities, connections to events and episodes related to each other (PALLER et al., 2013).

Coursaris and Sung (2012) argue that one of the main characteristics of interactivity is the variety of visual, sound, verbal and contextual stimuli that it provides its users, which is supported by Finkel et al.(2012). Another important characteristic of interactivity is the control that the user has when organizing information as they want it, in the sequence desired (STEUER, 1992; MERKT; SCHWAN, 2014) which according to Wood et al. (2011), favor explicit memory. 
Thus, this research aims to answer: Why does internet's interactivity increase male undergraduate user's explicit memory nearing course completion?

For Shapiro and Krishnan (2001), when the individual thinks deliberately on the information to which they were exposed, it is a mechanism for decision-making and it leads to the acquaintance with a type of event or information. Thus, explicit memory is an interactive way to obtain information for performing tasks. Thus, the overall objective of the research was to discover which Internet interactivity factors facilitate information recovery in order to increase the Explicit Memory, verifying the relationship between Interactivity (INTERA) and consumer's Explicit Memory (MEMO) in male undergraduate students nearing course completion.

Resuming the conceptions by Liu and Shrum (2009) and Ariely (2000), - the higher the interactivity, the greater the memory -, formulates the hypothesis that will be tested in the model shown in item 3:

Hypothesis: The higher the interactivity of an internet user the greater the memory of the navigated website.

\section{THEORETICAL MODEL}

In order to answer the research question, both the hypothesis as the proposed theoretical model are based on the definition of interactivity suggested by Steuer (1992) and explicit memory suggested by Lee (2002) and Shapiro and Krishnan (2001). Definitions lead us to constructs and their variables presented in table 1. Based on constructs and the assumption presented above, we then have the theoretical model to be investigated, presented in figure 1 . 


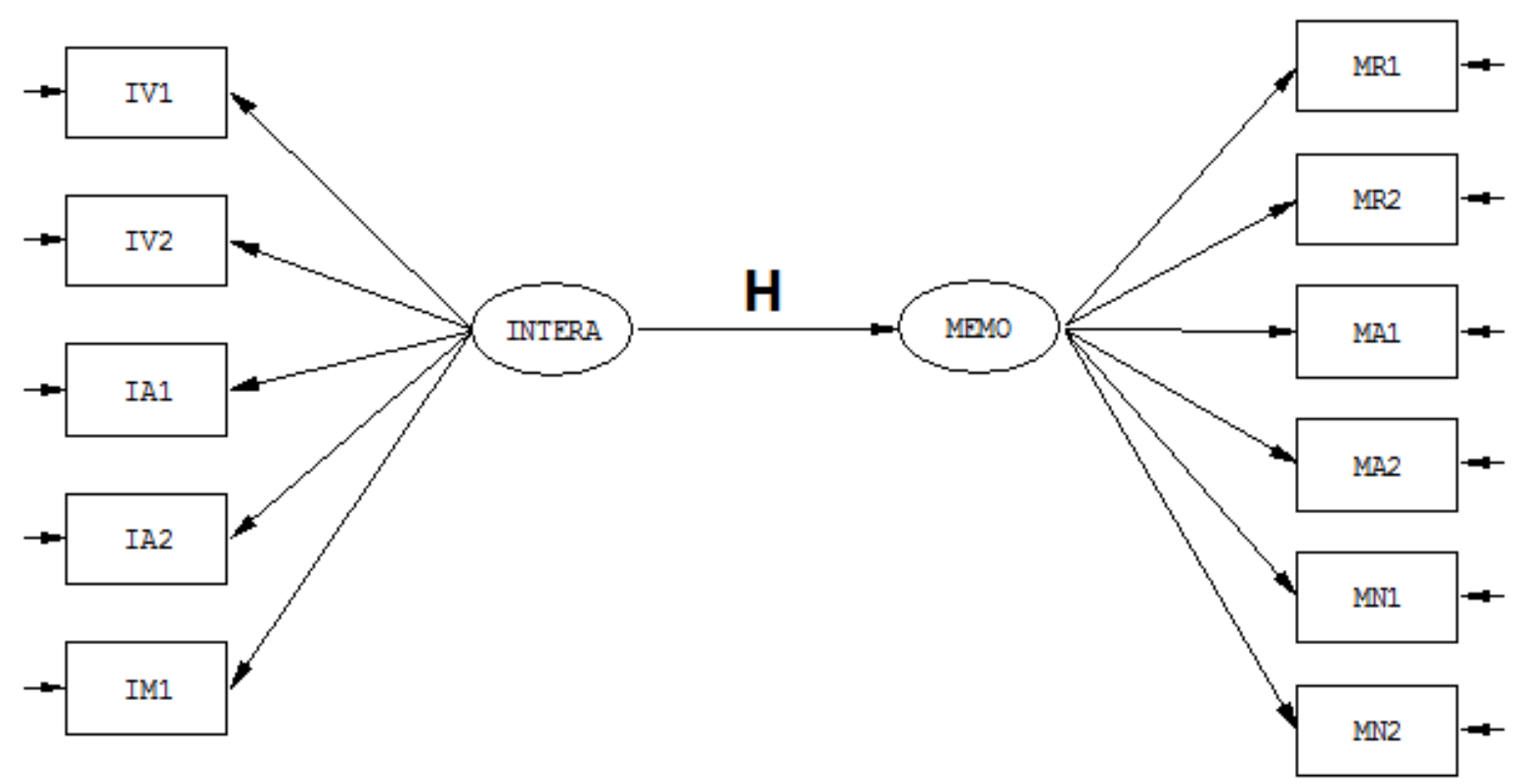

Figure 1 - Proposed model for the structural equation modeling

In the proposed model, Figure 1, the construct INTERA antecedes the construct MEMO. The variables related to the INTERA construct are those proposed by Steuer (1992): Speed, Radius, Range and Mapping. The variables that make up the MEMO construct are the knowledge of past events and its recognition through cognitive effort (LEE, 2002), represented by the recognition of what was seen, heard and done.

\section{METHODOLOGICAL PROCEDURES}

We used Structured Equation Modeling (SEM) in order to identify and analyze the evidences related to the INTERA and MEMO constructs. The constructs were subject to confirmation and verification of discriminant and convergent validity (PETER, 1981). We chose such method as it presents possibilities for studying relationships between latent variables and constructs, as is the case in this research. We thus sought to investigate and describe the concepts about INTERACTIVITY and EXPLICIT MEMORY, the interconnection between them and to determine the theoretical construct (SUN; HSU, 2012).

\subsection{SAMPLING AND DATA COLLECTION PROCESS}

For the selection of the sample, we considered the one which maximizes the validity of conclusions at the same time it minimizes the number of plausible alternatives consistent with the data (ALTMANN, 1974). For this purpose, to complete the internal validity, we sought a sample that eliminates or minimizes responses variability due to non-intrinsic variables of questions statements. Among these, Fang (2012), Cyr et al. (2009) and Arbaug and Benbunan-Fich (2007) reveal that age, gender, educational level and the use of internet are the variables that most influence both in the perception of interactivity as in memory in the 
Internet environment. Thus, we selected a homogeneous sample composed by young male undergraduate students, as described below.

In Brazil, the Internet has approximately 94.2 million users (IBOPE, 2013), and 60\% of these are university students (IBOPE/Netratings, 2013), and the male group represents 58\% (MKTEAM, 2012). Since this research investigates the Internet, the sample is characterized by people who use it the most. According to Walczuch and Lundgren (2004), undergraduate students are the most suitable for research involving the Internet, as they have free access to the Internet in their educational institutions, more opportunities it for personal communication purposes, for the search of academic and general information and business transactions such as buying books, among others. Cyr, Head and Ivanov (2009) assert that male students aged 20 to 21 years old are the most likely to participate in research and the most active in using the Internet with its varied resources.

Male undergraduate students were chosen as the INTERA and MEMO constructs are based on the diversity of uses that the Internet offers to its user as the e-mail and information related to work or leisure. Thus, we sought to investigate those who make use of the Internet regarding subjects, forms and time of use. For Correa et al. (2010), the male group prefers collective activities; the female group, individual ones; the male group prefers more complex commands; whilst the female group prefer the simpler ones; furthermore, the male group tends to search for more miscellaneous subjects and is more active and dynamic regarding the use of computer mediated environments. These characteristics of the male group indicate that it is best suited to the purposes of this research. As a selection criterion, we chose students who make daily and constant use of the Internet for their academic activities (hard users) (SUN; HSU, 2012; LIU; SHRUM, 2009).

By considering what was previously exposed, we defined as the target population of this research the group of male undergraduate students, in the year 2012, nearing the completion of the course of Business Management, as the average age of these students is 20 years, meeting the propositions by Cyr et al. (2009); this definition was based on similar surveys made by Kerlinger and Lee (2000). The college sampling was non-probabilistic by trial (COURSARIS; SUNG, 2012); the selection of participants, which aimed at the homogeneity of respondents, was done by filter by questions, considering their demographic characteristics, time of Internet use, participation in focus groups over the previous 12 months to the research and whether they are undergraduate students in their final year (SUN; HSU, 2012). 
Data were collected through a structured questionnaire containing closed questions, which were applied online and made available in a site created for this purpose. The sample came from volunteers and was based on list of students provided by the colleges registrar's offices, and through a draw were invited to participate in the research. Based on this initial list, they were requested to pass on this questionnaire through Facebook, to other undergraduates of their acquaintance, generating a snow ball effect, as suggested by Baltar and Brunet (2012) and Gjoka et al. (2011), obtaining the total of 453 respondents in 05 Universities in the city of São Paulo

For the validity of a minimum sample size, we adopted the propositions by Coursaris and Sung (2012) for whom the minimum sample size should be ten times greater than the number of variables of the most complex construct or ten times greater the number of independent variables that affect the dependent variable. In this study, we obtained 453 valid responses. Since the INTERA and MEMO constructs presented 5 and 6 variables respectively, totaling 11 independent variables, we thus have both conditions satisfied. The observation of these understandings originated the sample of this research composed initially by 876 male undergraduate students in nearing course completion, and 453 of them satisfactorily met the established items by the above authors.

\subsection{DATA ANALYSIS PLAN}

We performed a descriptive confirmatory analysis using LISREL 8.82 in order to check the model through discriminant and convergent validations. The sample size observed the procedures recommended by Coursaris and Sung (2012) for the Structural Equation Modeling (SEM), who propose that, at the very least, for the number of observations to be ten times greater than the number of variables. This study presents 11 variables and 453 observations, or valid questionnaires, thus satisfying the requirements proposed by these authors.

\subsection{VALIDATION AND RELIABILITY}

We performed the convergent validity through structural equations by determining which indicative variables have significant load in their specific constructs (ANDERSON; GERBING, 1988). This was performed by using the LISREL 8.82 software, by examining the value associated with the t-value with the respective value of the path coefficient (Lambda) (HAIR JUNIOR et al., 2006; BYRNE1989). The discriminant validation was conducted by limiting the estimated correlation parameter between pairs of components '1.00' and by performing the $\chi 2$ (chi-squared) difference test in the values obtained from the models containing limited pairs with the models whose pairs varied freely (BYRNE, 1989). 
We verified the reliability using the maxmincon principle (KERLINGER; LEE, 2000), that maximizes the variance of individual differences and minimizes the error's variance. Since the questionnaire was applied to five different schools, we conducted the same test on a single occasion for different groups with maximum dispersion of respondents (CYR et al. 2009). The estimation method adopted was the Unweighted Least Squares (ULS), because among the seven possible methods for SEM this one has no strict adherence assumptions of the measured variables or the ones measured at a multivariate normal distribution (GARSON, 2003).

\section{DATA ANALYSIS}

The analysis reveals variations between the proposed model and the resulting survey. The model resulting from the Structural Equations Modeling (SEM), figure 2, indicates that a variable previously linked to the construct INTERA (MA2) of the proposed model is linked to

the construct MEMO (see table 1), because the proposed model (figure 1) - despite presenting the following values in the goodness of fit tests: $\chi 2 / \mathrm{df}=2.78$; RMSEA $=.0787$; NFI $=1.000$; $\mathrm{NNFI}=1.000 ; \mathrm{CFI}=1.000 ; \mathrm{GFI}=.951$ and $\mathrm{AGFI}=.924$, which are considered as good presented high standardized residuals (between 3.71 and 7.58) for the variable "MA2" with other variables. Thus, a reanalysis led to the variable in question being removed from the INTERA construct and inserted into the MEMO construct, as it was verified that the variable's text (MA2) (The greater the variety of information that the user receives from a subject one is researching, the more one remembers the actions previously done), which could have induced the respondents to consider it with memory - the words "I remember" could have caused this interpretation. The change caused the residuals to stay within expected values. This aspect will be discussed later. 


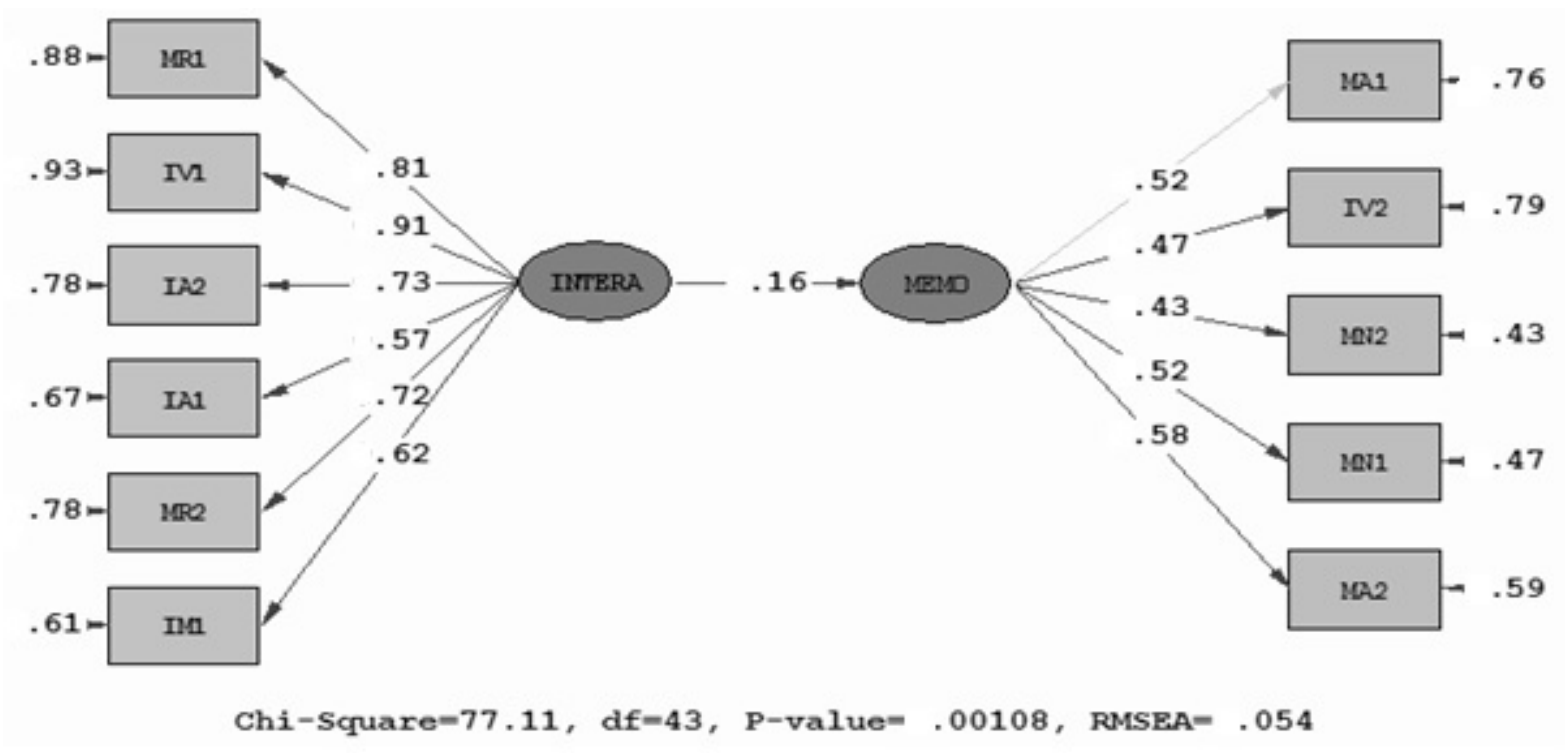

Figure 2 - Final Model adjusted for structural equation modeling.

Source: Elaborated by the authors.

It can be observed in figure 2 that the variables that make up the constructs INTERA and MEMO show high factor loadings for their constructs except for 'IM1 - Natural actions to the individual' (.07) and for 'IA1 - Total actions that the environment allows' (.23) with respect to the INTERA construct. This signals that the condition for the formation of interactivity is that the site will enable its users to do actions, even if they are few in amplitude. That is, the environment allows one to perform few actions, and these can be of different nature from those with which the Internet is used in the physical world.

The variables for the MEMO construct appear with strong factor loadings with this construct. This is evidenced with the variable with the lowest factor loading 'MA2 Associations have high factor loading with previous activities' (.67).

Figure 2 reveals that the constructs INTERA and MEMO are almost independent of each other due to the low path coefficient (.16) among the cited constructs. In this sense, the actions performed or that have the potential to be performed on a site does not have direct influence on memorization (MEMO).

We assessed the quality of the model by the calculation of six specific tests of the SEM method: weighted chi-square or the norm of $(\chi 2 / g 1)$, RMSEA - Root Mean Square Error of Approximation, NFI - Normed Fit Index, NNFI - Non-normed Fit Index, CFI - Comparative Fit Index, GFI - Goodness-of-Fit and AGFI - Adjusted Goodness-of-Fit (JÖRESKOG and SÖRBOM, 2002; PEDHAZUR, 1997). These values can be found in table 2 with their respective reference values. 
Table 2 - Calculated Values and Benchmarks of the Goodness-of-Fit of the SEM Model

\begin{tabular}{|l|c|c|}
\hline \multicolumn{1}{|c|}{ Model fit indices } & Calculated values & Reference values* \\
\hline$\chi 2 / d f($ chi-square/df) & 1.800 & $\chi 2 / g l=<5.0$ \\
\hline GFI (goodness-of-fit index) & .983 & GFI $>=.900$ \\
\hline AGFI (adjusted GFI) & .973 & AGFI $>=.900$ \\
\hline Normed Fit Index (NFI) & 1.000 & NFI $>=.900$ \\
\hline Tucker-Lewis Index (NNFI) & 1.000 & NNFI $>=.900$ \\
\hline Comparative Fit Index (CFI) & 1.000 & CFI $>=.900$ \\
\hline $\begin{array}{l}\text { RMSEA (Root Mean Square Error of } \\
\text { Approximation) }\end{array}$ & .0543 & RMSEA $=<.080$ \\
\hline
\end{tabular}

*see Hair Junior et al. (2006)

The analysis of the Fit indices of the model must be observed with caution, since the benchmark values, suggested by Maruyama (1998) and Straub, Boudreau and Gefen (2004), are not absolute limiting and do not represent limitations for the acceptance of the model. Nonetheless, we find that the goodness-of-fit indices of the model proved to be very suitable and indicate that the model can be analyzed.

The final model (see figure 2) presents strong evidence that interactivity is a concept related to actions that the user does or can do, as revealed by variables MR1, IV1, IA2, IA1, MR2 and IM1". It is interesting to note that interactivity has two dimensions: (a) one that is relative to the past - as "MR1 - the user knowing where to click", which is a dimension that incorporates knowledge (or memory), to indicate what to do in the present moment and (b) another relative to the action in the future, "MR2 - the user expects what will happen before they click, that is, they do not expect surprises such as receiving unwanted "banner ads". In this case, interactivity represents actions and performance expectations about what can still happen.

Residuals appeared to be very appropriate, since only $6 \%$ were outside the recommended values range of \pm 2.58 (MARUYAMA, 1998). The values for the $t$ Student tests between the variables and the constructs appeared above 1.96, indicating that the values of the regression coefficients between variables to constructs (MARUYAMA, 1998) are significant $(\mathrm{p}<.05)$ and, therefore, not rejected.

Finally, we calculate the value of the Cronbach's alpha and Composite Reliability tests in order to verify the model's one-dimensionality and reliability (CRONBACH, 1971). The values obtained were: Cronbach's alpha: INTERA $=.843$ and MEMO $=.768$; for Composite Reliability values resulted in: INTERA $=.817$ and MEMO $=.771$. As the recommended values are .60 and .70 respectively (BENTLER, 1991), the sample has few biases and can be 
considered appropriate. This research provides strong indicators that interactivity may represent actions and their consequences in the future.

\section{FINAL CONSIDERATIONS}

This research provided a theoretical contribution that allows the identification of the factors that comprise interactivity and the relational nature of these factors with the formation of the explicit memory of the male undergraduate consumer nearing course completion on the Internet.

Figure 2 reveals that a very low causal relationship (path coefficient $=.16$ ) between interactivity and explicit consumer memory; while the path coefficient (BENTLER, 1991of these constructs is low, the model proves to be appropriate, reliable and valid (chi-square $=$ 77.11; p-value $\leq .001$; RMSEA $=.054)$, but it shows that there is a fine causal relationship between the two constructs. This finding shows that studies previously conducted with television as the explicit consumer memory (BRAUN-LATOUR; LATOUR, 2004) cannot be applied to the Internet and its effects on explicit memory; that is, the results of this research provide evidence that conclusions about the effects of television on explicit memory cannot be applied to the Internet environment due to the fact that interactivity precedes explicit consumer memory on the Internet.

Thus, we can observe that the final model (figure 2) is composed by the constructs INTERA and MEMO and that the construct INTERA presents strong evidence of being explained by the variables:

a) "Visual Acknowledgement", formed by MR1 - the user knows where to click to get the desired information and by MR2 - the user has expectation of what will happen before they click, that is, they do not expect surprises like unwanted 'banners';

b) "Speed", formed by IV1 - possibility of actions that alter the environment and IA 2 - the possibility of the user organizing information as they want;

c) "Reach", formed by IA1 - total actions that the environment allows - and "Mapping", formed by IM1 - natural actions for the individual.

The construct MEMO is explained by the variables:

a. a) "Number of associations", formed by MA1 - for a given information, the user associates it with others - and MA2 - associations have high correlation 
with previous activities;

b. b) "Speed", formed by IV2 - response time of the site to a request that was made;

c. "Sensory-motor recognition", formed by MN2 - words are more easily remembered than images - and MN1 - for a given task, the user remembers several episodes of how to accomplish it.

We can observe that there is strong evidence that these variables represent and explain the formation of these constructs to the public studied.

Another contribution is with respect to the interactivity concept. Published research and definitions assert that interactivity has a relationship with previous messages (RAFAELI; SUDWEEKS, 1997). This research revealed that interactivity may represent future actions, or something related to what will happen according to user's expectations of the media. In this case, the findings of this research contribute to the expansion of the concept of interactivity. The concepts relating to interactivity are based on actions or associations to past events, such as a message being associated to other previous messages as asserted by Rafaeli and Sudweeks (1997). These results provide evidence that interactivity may be related to future events, that is, concerning the expectations that the user has about their interests.

The final model, figure 2, is valid for the researched sample, presenting a good level Fitting (RMSEA $=.054)$. This model presents strong evidence that the constructs INTERA and MEMO are very weakly dependent on each other. That is, they show a low degree of dependence (path coefficient $=.16$ ). The low degree of dependency between the constructs signals that the memory formation is more related with the interest of the Internet user than with the ease of dealing with the site (LOMBARD; SNYDER-DUCH, 2001). This is an important aspect, since interactivity can be a factor to disperse the attention of the user of the site in question, which could imply lower memorization. In this sense, the results of this research show that factors such as maximum utility adaptation and hand dexterity among others, as asserted by Lombard and Snyder-Duch (2001), are not relevant factors to the formation of greater interaction and explicit memory. Conversely, the results of this research suggest that the Uses and Gratifications Theory, as stated by McMahan et al. (2010), is applicable to the Internet, and explains the formation of interactivity in this media.

When we observe the variables which compose the construct MEMO, there is strong incidence of associations as a facilitating element for the explicit memory of male 
undergraduate students nearing course completion. Thus interactivity, for being an element that establishes a sequence of actions for consumers to achieve their goals (future actions or expectations), it can then become an influencing element for the explicit memory element of that consumer, which is explained by the Uses and Gratifications Theory.

In short, although there is no strong relationship between interactivity and explicit memory, the resulting model of this research provides evidence that interactivity - as a factor that guides the consumer's actions in the search for their goals - it can be an influencing element of the memorization of elements undertaken by Internet users, a fact that had not yet been pointed out by the literature and analyzed in this study.

Finally, a limitation of this research is the sample, which consists of male undergraduate students nearing their business management course completion, which prevents generalizations to other populations. Another limitation is that the sample was nonprobabilistic, which limits the generalization of the results obtained.

In this sense, the main suggestion is the replication of this study in order to verify the proposed model for other crowds and populations and, where applicable, with a probabilistic sample.

\section{CONTRIBUTIONS BY THE AUTHORS}

George Bedinelli Rossi: has elaborated research objective, participated in the development of the theoretical framework, sample and sampling definition, constructs definition and hypothesis elaboration, construction of the measurement scale, data analysis technique, data analysis and final consideration.

Dirceu da Silva: participated in the development of the theoretical framework, sample and sampling definition, constructs definition and hypothesis elaboration, construction of the measurement scale, data analysis technique, data analysis and final consideration.

Mauro Neves Garciat: participated in the development of the theoretical framework, sample and sampling definition, constructs definition and hypothesis elaboration, construction of the measurement scale, data analysis technique, data analysis and final consideration.

\section{REFERENCES}

ARBAUGH, J. B.; BENBUNAN-FICH, R. The importance of participant interaction in online environments. Decision Support Systems, v.43, n.3, p. 853-865, 2007.

ANDERSON, J. C.; GERBING, D. W. Structural equation modeling in practice: A review and recommended two-step approach. Psychological Bulletin, v.103, n.3, p.411-442, 1988. 
ARIELY, D. Controlling the Information Flow: Effects on Consumers' Decision Making and Preferences, Journal of Consumer Research, v.27, n.2, p.233-248, 2000.

ALTMANN, J. Observational study of behavior: sampling methods. Behaviour, v. 49, n. 3, p. 227-266, 1974.

BALTAR, F.; BRUNET, I. Social Research 2.0: virtual snowball sampling method using Facebook. Internet Research, v.22, n.1, p. 58-74, 2012.

BARTLETT, F. C. Remembering. Scientia, v. 57, p. 221-226, 1935.

BARON-COHEN, S.; KNICKMEYER, R. C.; BELMONTE, M. K. Sex differences in the Brain: Implications for explaining Autism, Science, v.310, n.5749, 2005.

BELLMAN, S., ROSSITER, J. R. The website schema. Journal of Interactive Advertising, v.4, n.2, p.1-16, 2004.

BENTLER P. Comparative fit indices in structural models. Psychological Bulletin, v.107, n.2, p. 238-46, 1991.

BRAUN-LATOUR, K. A.; LATOUR, M. S. Assessing the long-term impact of a consistent advertising campaign on consumer memory. Journal of advertising, v.33, n.2, p.49-61, 2004.

BYRNE, B. M. A primer of LISREL: Basic applications and programming for confirmatory factor analytic models. New York: Springer-Verlag, 1989. 412p.

COHEN, N. J.; POLDRACK, R. A.; EICHENBAUM, H. Memory for items and memory for relations in the procedural/declarative memory framework. Memory, v.5, n. 1-2, p. 131-178, 1997.

CORREA, T.; HINSLEY, A. W.; GIL de ZÚÑIGA, H. Who interacts on the Web? The intersection of users' personality and social media use. Computers in Human Behavior, v.26, n.2, p.247-253, 2010.

COSGROVE, K. P.; MAZURE, C. M.; STALEY, J. K. Evolving knowledge of sex differences in brain structure, function, and chemistry. Biological Psychiatry, v.62, n.8, p. 847-855, 2007.

COURSARIS, C. K.; SUNG, J. Antecedents and consequents of a mobile website's interactivity. New Media \& Society, v.14, n.7, p.1128-1146, 2012.

COYLE, J. R.; THORSON, E. The effects of progressive levels of Interactivity and Vividness in Web Marketing Sites. Journal of Advertising, v.30, n.3, p.65-77, 2001.

CRONBACH, L. Test validation. In: THORNDIKE, R. (Ed.). Educational measurement. 2. ed. Washington: American Council on Education, 1971. p.443-507.

CYR, D.; HEAD, M.; IVANOV, A. Perceived interactivity leading to e-loyalty: development of a model for cognitive-affective user responses. International Journal of Human-

Computer Studies, v.67, n.10, p.850-869, 2009. 
DOMAGK, S.; SCHWARTZ, R.N.; PLASS, J.L. Interactivity in multimedia learning: an integrated model. Computers in Human Behavior, v.26, n.5, p.1024-1033, 2010.

FANG, Y.-H. Does online interactivity matter? Exploring the role of interactivity strategies in consumer decision making. Computers in Human Behavior, v. 28, n.5, p. 1790-1804, 2012.

FINKEL, E. J. et al. Online dating: a critical analysis from the perspective of psychological science. Psychological Science in the Public Interest, v.13, n.1, p.3-66, 2012.

GARSON, G. D. PA 765 Statnotes: an online textbook. 2003. Disponível em: <http://www2.chass.ncsu.edu/garson/pa765/statnote.htm>. Acesso em: 24 abr. 2015.

GJOKA, M. et al. Practical recommendations oncrawling online social networks. IEEE Journal on Selected Areas in Communications, v.29, n.9, p.1872-1892, 2011.

GRIFFITH, D.; CHEN, Q. The influence of virtual direct experience on online ads message effectiveness. Journal of Advertising, v.33, n.1, p.55-69, 2004.

HAIR JUNIOR, J. F. et al. Multivariate data analysis. 6. ed. Upper Saddle River: Prentice Hall, 2006. 688p.

IBOPE. 94,2 milhões de pessoas tem acesso à internet no Brasil. Disponível em: $<$ http://www.ibope.com.br/pt-br/relacionamento/imprensa/releases/Paginas/942- milhoes-depessoas-tem-acesso-a-internet-no-Brasil.aspx>. Acesso em: 20 mar. 2013.

IBOPE/NETRATINGS. Disponível em: <http://www2.ibope.com.br>. Acesso em: 1 out. 2013.

JIANG, Z. et al. Effects of interactivity on website involvement and purchase intention. Journal of the AIS, v.11, n.1, p. 34-59, 2010.

JOHNSON, G. J.; BRUNER II, G. C.; KUMAR, A. Interactivity and its facets revisited theory and empirical test. Journal of Advertising, v. 35, n.4, p. 35-52, 2006.

JÖRESKOG, K.; SÖRBOM, D. LISREL 8: user's reference guide. 2. ed. Chicago: Scientific Software International, 2002. 383p.

KAN, I. P. et al. Implicit memory for novel associations between pictures: effects of stimulus unitization and aging. Memory \& Cognition, v.39, n.5, p.778-790, 2011.

KEMP, N. J. et al. Visual communication and impression formation. British of Social Psychology, v.23, n.2, p.133-145, 1984.

KERLINGER, F. N.; LEE, H. B. Foundations of behavioral research. 4. ed. London: Thomson Learning, 2000. 890p.

KIM, J.; SPIELMANN, N.; MCMILLAN, S. J. Experience effects on interactivity: functions, processes and perceptions. Journal of Business Research, v.65, n.11, p.1543-1550, 2012.

KO, H., CHO, C., ROBERTS, M. Internet uses and gratifications: a structural equation model of interactive advertising. Journal of Advertising, v.34, n.2, p.57-70, 2005. 
LAVIE, N. Attention, distraction, and cognitive control under load. Current Directions in Psychological Science, v.19, n.3, p.143-148, 2010.

LEE, A. Y. Effects of implicit memory on memory-based versus stimulus-based brand choice. Journal of Marketing Research, v.39, n.4, p.440-454, 2002.

LIU, Y.; SHRUM, L. J. A dual-process model of interactivity effects. Journal of Advertising, v.38, n.2, p.53-68, 2009.

LOMBARD, M., SNYDER-DUCH, J. Interactive advertising and presence: a framework. Journal of Interactive Advertising, v.1, n.2, p.1-14, 2001.

MAK, A. K. Y. et al. Sex-related differences in neural activity during emotion regulation. Neuropsychologia, v.47, n.13, p.2900-2908, 2009.

MARSH, R. L., COOK, G. I., HICKS, J. L. Task interference from event-based intentions can be material specific. Memory \& Cognition, v.34, n.2, p.1636-1643, 2006.

MARUAYAMA, G. M. Basics of structural equation modeling. Thousand Oaks: Sage Publications, 1998. 311p.

McMAHAN, C.; HOVLAND, R.; McMILLAN, S. Online marketing communications: exploring online behavior by examining gender differences and Interactivity within Internet Advertising. Journal of Interactive Advertising, v.10, n.1, p. 61-76, 2010.

MEILÁN, J. J. G. et al. Intention superiority effect on implicit memory of shopping lists: activation and inhibition processes. Motivation and Emotion, v.35, n.2, p.144-150, 2011.

MERKT, M.; SCHAN, S. How does interactivity in videos affect task performance? Computers in Human Behavior, v. 31, Feb., p. 172-181, 2014.

MKTEAM. E-commerce. Disponível em: <http://www.mkteam.com.br>. Acesso em: 28 set. 2012.

MUDAMBI, S. M.; SCHUFF, D. What makes a helpful online review? A study of customer reviews on Amazon.com. MIS Quarterly, v.34, n.1, p.185-200, 2010.

MULLIGAN, N. W. Differentiating between conceptual implicit and explicit memory: a crossed double dissociation between category-exemplar production and category-cued recall. Psychological Science, v.23, n.4, p.404-406, 2012.

NEISSER, U. Cognition and reality: principles and implications of cognitive psychology. New York, NY: W. H. Freeman and Co, 1976.

PALLER, K. A.; VOSS, J. L.; WESTERBERG, C. E. Investigating the awareness of remembering. Perspectives on Psychological Science, v.4, n.2, p.185-199, 2013.

PEDHAZUR, E. J. Multiple regression in behavioral research: explanation and prediction. 3. ed. Fort Worth: Harcourt Brace College Publishers, 1997. 587p.

PETER, J. P. Construct validity: a review of basic issues and marketing practices. Journal of Marketing Research, v.18, n.2, p.133-145, 1981. 
RAFAELI, S.; SUDWEEKS, F. Networked interactivity. Journal of Computer-Mediated Communication, v.2, n.4, p.1-6, 1997.

REGAN, D. Perceptual motor skills and human motion analysis. In: SALVENDY, G. (Ed.). Handbook of human factors and ergonometrics. 2. ed. New York: John Wiley \& Sons, Inc., 1997. p.174-218.

ROEDIGER, H. L. Implicit memory: retention without remembering. American Psychologist, v.5, n.9, p. 1043, 1990.

RUBIN, R. D. et al. How do i remember that i know you know that i know? Psychological Science, v.22, n.12, p.1574-1582, 2011.

SCHACTER, D. L. Searching for memory: the brain, the mind, and the past. New York: Basic Books, 1996. 402p.

SHAPIRO, S.; KRISHNAN, H. S. Memory-based measures for assessing advertising effects: A comparison of explicit and implicit memory effects. Journal of Advertising, v.30, n.3, p.1$13,2001$.

SIMMONS, C. Dear radio broadcaster: fan mail as a form of perceived interactivity. Journal of Broadcasting \& Electronic Media, v.53, n.3, p.444-459, 2009.

STEUER, J. Defining virtual reality: dimensions determining telepresence. Journal of Communication, v.42, n.4, p.73-93, 1992.

STRAUB, D.; BOUDREAU, M. C.; GEFEN, D. Validation guidelines for IS positivist research. Communications of AIS, v.13, n.24, p.380-427, 2004.

STROMER-GALLEY, J. On-line interaction and why candidates avoid it. Journal of Communication, v.50, n.4, p.111-133, 2000.

SUN, J. N.; HSU, Y. C. An experimental study of learner perceptions of the interactivity of web-based instruction. Interacting with Computers, v.24, n.1, p.35-48, 2012.

SWELLER, J. Element interactivity and intrinsic, extraneous, and germane cognitive load. Educational Psychology Review, v.22, n.3, p.123-138, 2010.

SZPUNAR, K. Evidence for an implicit influence of memory on future thinking. Memory $\&$ Cognition, v.28, n.5, p.531-540, 2010.

TOTH, J. P.; HUNT, R. R. Not one versus many, but zero versus any: Structure and function in the context of the multiple memory systems debate. In: FOSTER, J.K.; JELICIC, M (Eds.). Memory: systems, process, or function? Oxford, England: Oxford University Press, 1999. p. 233-272.

TULVING, E. Episodic memory: from mind to brain. Annual Review of Psychology, v. 53, p. 764-781, fev. 2002.

VAN NOORT, G.; VOORVELD, H. A. M.; VAN REIJMERSDAL, E. A. Interactivity in brand web sites: cognitive, affective, and behavioral responses explained by consumers' online flow experience. Journal of Interactive Marketing, v.26, n.4, p.223-234, 2012. 
VAN NOORT, G.; WILLEMSEN, L. M. Online damage control: the effects of proactive versus reactive web care interventions in consumer-generated and brand-generated platforms. Journal of Interactive Marketing, v.26, n.3, p.131-40, 2012.

VERDE, M. Associative interference in recognition memory: a dual-process account. Memory \&Cognition, v.32, n.8, p.1273-1284, 2004.

VOORVELD, H. A. M.; NEIJENS, P. C.; SMIT, E. G. The relation between actual and perceived interactivity: what makes the web sites of top global brands truly interactive? Journal of Advertising, v.40, n.2, p.77-92, 2011.

WALCZUCH, R.; LUNDGREN, H. Psychological antecedents of institution-based consumer trust in e-retailing, Information \& Management, v.42, n.1, p.159-177, 2004.

WELDON, M. S; MASSARO, D. W. Integration of orthographic, conceptual and episodic information on implicit and explicit tests. Canadian Journal of Experimental Psychology, v.50, n.1, p.72-86, 1996.

WOOD, R.; BAXTER, P.; BELPAEME, T. A review of long-term memory in natural and synthetic systems. Adaptive Behavior, v.20, n.2, p.81-103, 2011. 